\title{
PLK3 wt Allele
}

National Cancer Institute

\section{Source}

National Cancer Institute. PLK3 wt Allele. NCI Thesaurus. Code C51198.

Human PLK3 wild-type allele is located in the vicinity of 1 p34.1 and is approximately $6 \mathrm{~kb}$ in length. This allele, which encodes serine/threonine-protein kinase PLK3 protein, plays a role in the regulation of $\mathrm{M}$ phase functions during the cell cycle. The PLK3 gene is downregulated in certain types of cancer (head and neck squamous cell carcinomas, lung carcinomas) and overexpressed in other types of cancer (breast carcinomas and highlyproliferating malignant epithelial ovarian tumors). 